\title{
Developing Student-Centered Learning Model to Improve High Order Mathematical Thinking Ability
}

\author{
Sahat Saragih ${ }^{1} \&$ Elvis Napitupulu ${ }^{1}$ \\ ${ }^{1}$ Mathematic Education Science Faculty, State University of Medan, Indonesia \\ Correspondence: Sahat Saragih, Jl. Willem Iskandar Pasar V Medan, 20221, North Sumatera, Indonesia. Tel: \\ 62-81-2652-0733. E-mail: saragihpps@gmail.com
}

Received: January 22, 2015 Accepted: February 22, 2015 Online Published: May 28, 2015

doi:10.5539/ies.v8n6p104 URL: http://dx.doi.org/10.5539/ies.v8n6p104

\begin{abstract}
The purpose of this research was to develop student-centered learning model aiming to improve high order mathematical thinking ability of junior high school students of based on curriculum 2013 in North Sumatera, Indonesia. The special purpose of this research was to analyze and to formulate the purpose of mathematics lesson in high order mathematical thinking ability and also to develop and to try-out the learning model developed. The subject of the research was 7th graders from state and private Junior High School in Medan and Deli Serdang, which were taken proportional randomly. It was elected SMP N 36, SMPN 2 Tembung, and private SMP Bandung Bandar Khalifah. This developmental Research that orientated on developing product was done in three steps. From the first step, it was revealed that either lesson preparation (students' book, teachers' guided, and lesson material) or the instrument was judged valid and need only a little revision. Analysis on data revealed that the students' high order thinking ability especially in mathematical problem solving, mathematical understanding, and mathematical communication enhanced significantly. By analysis, the reliability of instruments on mathematical understanding, mathematical problem solving, and mathematical communication ability was categorized good.
\end{abstract}

Keywords: student-centered learning model, high order mathematical thinking

\section{Introduction}

The purpose of mathematics lesson in elementary, middle level school, and university is to prepare students to be able to adapt in the ever changing life and in the developing world, through training that focused on logical basic thinking, rationale, critical, accurate, honest, efficient and effective (Puskur, 2005). Besides, the students are expected to use mathematics and mathematical mindset in daily life, and to study many kinds of sciences which stress to logical arrangement and student's character building and also ability to apply mathematics. It deals with mathematics vision which it is to fulfill the nowadays and future necessity.

According to Sumarno (2005), the first vision leads to mathematics learning for conceptual understanding and mathematics idea which will be applied in order to solve routine and non routine, logical, communicative and other sciences (low and high mathematical thinking). The second vision in more wider definition and leading to future, mathematics gives logical, systematical, critical and scrupulous ability; developing creativity, habit of working hard and independent, impartiality, discipline, and social attitude; rising self confidence, sense of beauty to the regularity of mathematics; also developing objective and open-minded needed to face the future which is always changing.

In order to achieve the objective of mathematics learning above, most of the teachers teach mathematics by explaining the concepts and mathematical operation, give examples to answer questions, a little bit debriefing (if any). Then the session continued by asking the students to answer the similar questions with what the teacher has explained. Such learning activity was also found by the researchers when engaged in Diklat PLPG in Medan from 2008 untill 2013 and in Saragih $(2007,2009,2010)$. Here are some findings on such model of teaching and learning. The teacher gave his students a routine exercise and worked to solve.

Determine the set solution of this equations system. $3 x+3 y=10.500$ and $6 x+5 y=20.000$.

All the teachers used elimination, substitution, and also chart methods to resolve it. Started by giving solution example, then giving exercise questions suitable to the examples has been given. 
While teaching scale concept, teachers in general directly use the formula below:

$$
\text { Scale }=\frac{d m}{d r}
$$

which $\mathrm{dm}=$ distance in map and $\mathrm{dr}=$ distance in reality.

Lack of teachers' attention on independence of students' thinking makes instructional process to be more likely to train student's logical thinking and only stress to remembering mathematical concepts and procedures in order to answer questions. Students do not have other alternate thinking in responding to the questions. In case difficulties emerge, the students do not have another grip as guidance. The students will use descent procedure (Carroll \& Porter, 1998) since lack of meaningful comprehension of algorithm they use. The impact is both vision and the objectives of mathematics learning are not achieved. Similar opinion also states by Marpaung (2001), Zulkardi (2001), and Darhim (2004). According to Herman (2006), this learning activity does not accommodate the development of students' ability to solve problems, logical thinking, mathematical connection and communication (high mathematical thinking level).

Cooney (Sumarno, 2005) suggests mathematical learning reformation by means of replacing learning approach from immitating to learning with understanding which is based on the opinion that "knowing that" is a thing which must be done in the effort to achieve mathematics vision and the expected objective of mathematics learning. In the case of doing math which is presented in opened problems, students are expected to be able to check, explore, communicate, make conjecture, submit justification and arrange argument. Problem based (presenting non routine problem or open problem which need cognitive and metacognitive strategy) is one of the promoting approach that is believed be able to endorse creative and higher level thingking, study in group or interactive based on students-centered learning.

A number of former study (Saragih, 2007, 2009, 2010; Herman, 2006; Dahlan, 2003; Suryadi, 2005; Haji, 2005) which implemented many kinds of constructivist approaches report that improvement of high level thinking such as logical thinking ability, communication ability, logical understanding, comprehension, mathematical connection of senior high school students with positive mathematical studying attitude take place. An interesting problem is to seek a student-centered learning model that promotes high level mathematical thinking.

\section{Research Method}

\subsection{Research Approach}

This study was a developmental research. Richey and Nelson in Armanto (2008) identified that developmental research is oriented to product development where the developmental process is described as accurate as possible and then product is evaluated. Van den Akker (1999) stated it as a formative research where the research activity is done in cyclic process and objected to optimalize the quality of product implementation in certain situation. In mathematics learning, developmental research is applied in cyclic activities from designing and examining the material product of mathematics learning (Gravemeijer, 1999). The results of the research were qualified product theoretically, procedural and empirical methodology.

The research activities are conducted in three steps. The three steps are figured as follow: 


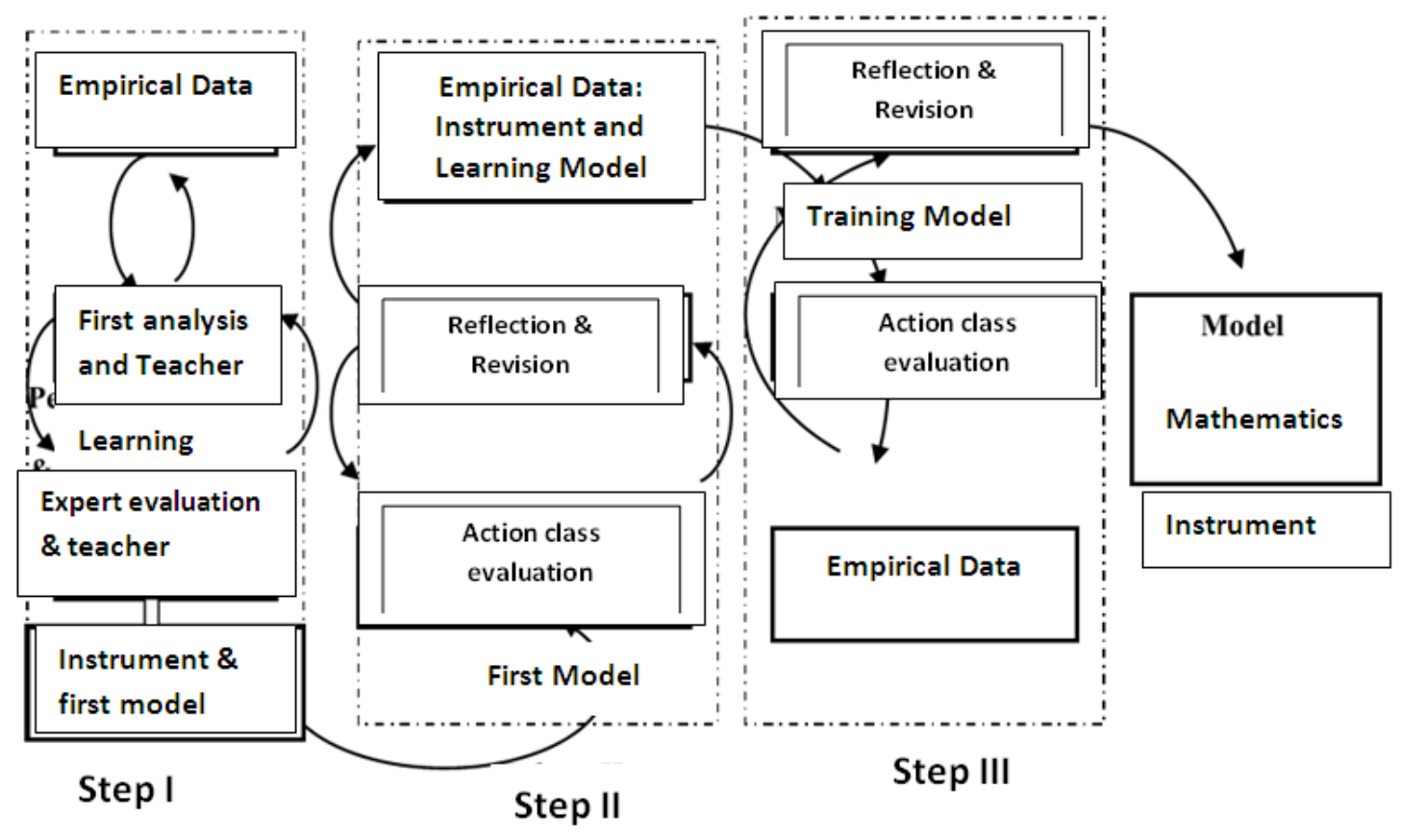

Figure 1. Research Step and activity of developmental research

The first step of is called front-end analysis which is intended to analyze empirical data to determine high level mathematical thinking which the students have to grasp by considering 2013 curriculum. This activity is followed by designing a mathematics learning model which is arranged based on constructivist mathematics learning theory. By justification, analysis and evaluation of mathematics experts and competent teachers of senior high school such that First Model of mathematics learning in the first grade of senior high school is developed. This research includes curriculum development experts from Education Office in North Sumatera and other experts of mathematics learning. A part of instruments determine First Model of high mathematical thinking level of which the realistic mathematics approach has been developed by researcher (Saragih, 2007, $2009,2010)$. The first activity is conducted in the first months of this research.

The data for the first step is collected from many kinds of measurement technique, such as field observation (concerning with condition, situation, and culture live in North Sumatera). Also documentation (picture and North Sumatera illustration context which reflect mathematics elements in it), and deep interview. Analysis of high mathematical thinking level ability in 2013 Curriculum and adjusted to the documentary data about condition, situation and North Sumatera culture which have mathematics elements in it are important aspects to develop First Model of mathematics learning for senior high school students.

\subsection{Population and Sample of the Research}

The population of this research is all the public and private first grade Junior High school students in North Sumatera. Samples were chosen purposively and adjusted to the sub research design. The samples in the first step were he students of SMP Negeri 2 Tembung and SMP Swasta Bandung. Six mathematics education students were engaged in this research.

\subsection{Technique of Collecting Data and Analyzing Data}

Some techniques were used to collect data such as high level mathematics thinking ability test, questionnaire, and observation sheet. The test was used to analyze the students' comprehension in high-level mathematics thinking ability. Questionnaire was used to know the attitude of the students in the case of learning process and mathematics concepts. Meanwhile, the observation sheet was used to know the degree of learning model implication applied in the classroom towards teachers and students' activities in instructional process.

\subsection{Research Systematic}

High-level mathematical thinking as a goal of the learning process remains a serious problem. It directly implies to the vision and goals of mathematics education that achieved not fit to what expected. There is some aspects influence high mathematical thinking level ability such as teacher, students, method/approach of learning, 
mathematics material, accommodations. Generally, the problem in this research can be visualized in Fishbone Diagram below.

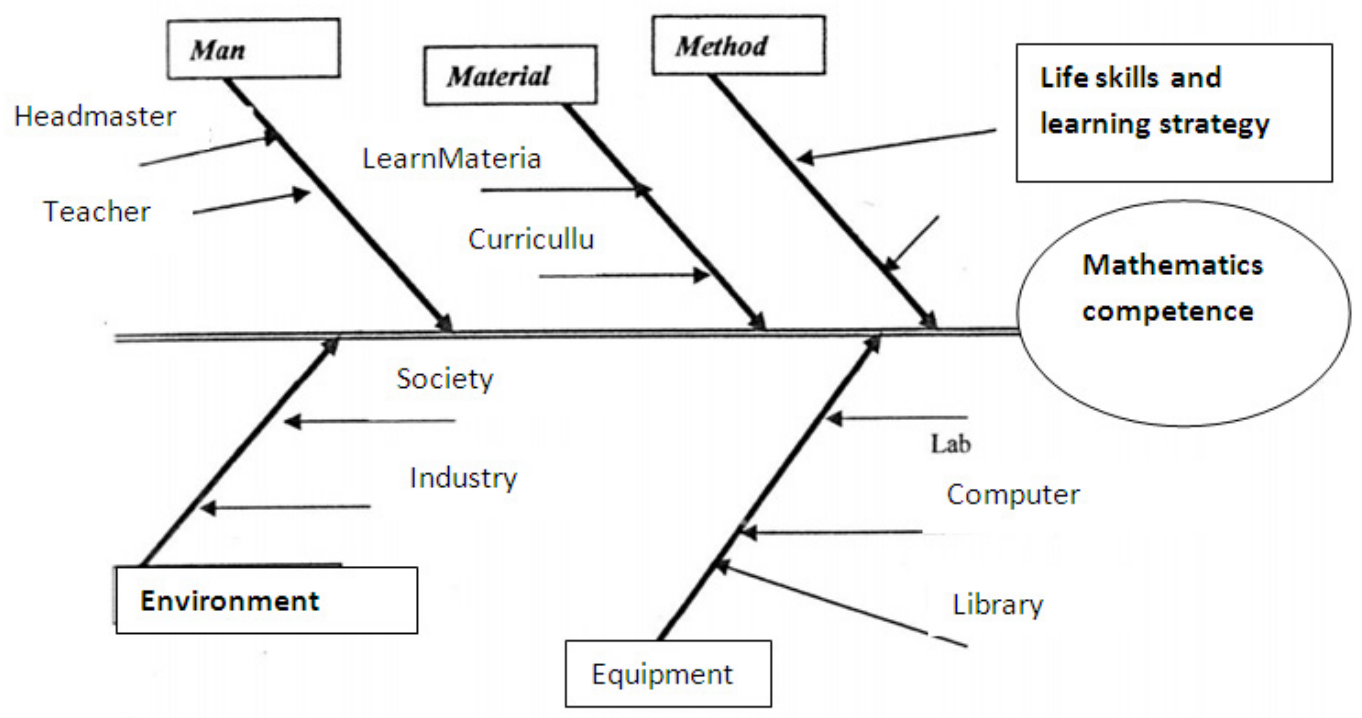

Figure 2. Fishbone research diagram

Of the content, prerequisite material would be adjusted; the accordance of concept to the student's cognitive level would be fitted; the fitness of the context to the students' daily life will be discussed to formulate characteristic of high mathematical thinking level. Of the teaching model or approach, many of them suitable to the students-centered learning will be explored. The teacher's ability to design and develop learning material suitable to the students-centered learning model will be elaborated thoroughly on teacher aspect. The improvement of high mathematical thinking ability level and the students' positive attitude toward mathematics and learning model as impact of learning process will be discussed in student aspect. Moreover, supporting equipment, library, laboratory, and school environment in conducting learning process will be studied. The school society discussed in general, endorsement of higher education as expert supplier and human resources to achieving improvement in education will be explored.

Based on figure above, steps done in this research are developing and designing students-centered learning model and also formulating high mathematical thinking level of junior high school students' competence.

\section{Findings and Discussions}

The research findings indicate that either lesson plan or instrument was judged valid by validators. Empirical data indicated that the entire instrument has validity and reliability of high category. The reliability of mathematical concept understanding test was 0.744 , mathematical problem solving was 0.88 , and mathematical communication was 0.788 . The validity of each test was in the table below consecutively.

Table 1. Validity of mathematical concept understanding test

\begin{tabular}{lllll}
\hline No & $\mathrm{r}_{x y}$ & $\mathrm{~T}_{\text {observe }}$ & $\mathrm{T}_{\text {table }}$ & Interpretation \\
\hline 1 & 0.89 & 9.08 & 2.05 & Valid Significant \\
2 & 0.82 & 6.92 & 2.05 & Valid/Significant \\
3 & 0.74 & 8.34 & 2.05 & Valid/Significant \\
4 & 0.71 & 6.26 & 2.05 & Valid/Significant \\
\hline \multicolumn{5}{l}{ Reliability } \\
\hline
\end{tabular}


Table 2. Validity of mathematical problem solving test

\begin{tabular}{lllll}
\hline No & $\mathrm{R}_{x y}$ & $\mathrm{~T}_{\text {observe }}$ & $\mathrm{t}_{\text {table }}$ & Interpretation \\
\hline 1 & 0.64 & 10.41 & 2.05 & Valid Significant \\
2 & 0.69 & 10.00 & 2.05 & Valid/Significant \\
3 & 0.57 & 8.69 & 2.05 & Valid/Significant \\
4 & 0.64 & 7.59 & 2.05 & Valid/Significant \\
\hline \multicolumn{5}{l}{ Reliability Statistics $(\mathrm{R})=0.88$} \\
\hline
\end{tabular}

Table 3. Validity of mathematical communication test

\begin{tabular}{lllll}
\hline No & $\mathrm{r}_{x y}$ & $\mathrm{~T}_{\text {observe }}$ & $\mathrm{t}_{\text {table }}$ & Interpretation \\
\hline 1 & 0.89 & 10.41 & 2.05 & Valid/Significant \\
2 & 0.82 & 10.00 & 2.05 & Valid/Significant \\
3 & 0.74 & 8.69 & 2.05 & Valid/Significant \\
4 & 0.71 & 7.59 & 2.05 & Valid/Significant \\
\hline \multicolumn{5}{l}{ Reliability Statistics $(\mathrm{R})=0.788$} \\
\hline
\end{tabular}

In addition, picture used in student sheet was revised to make it more interesting and clear. The sheet can be seen in the Figure 3 below. 


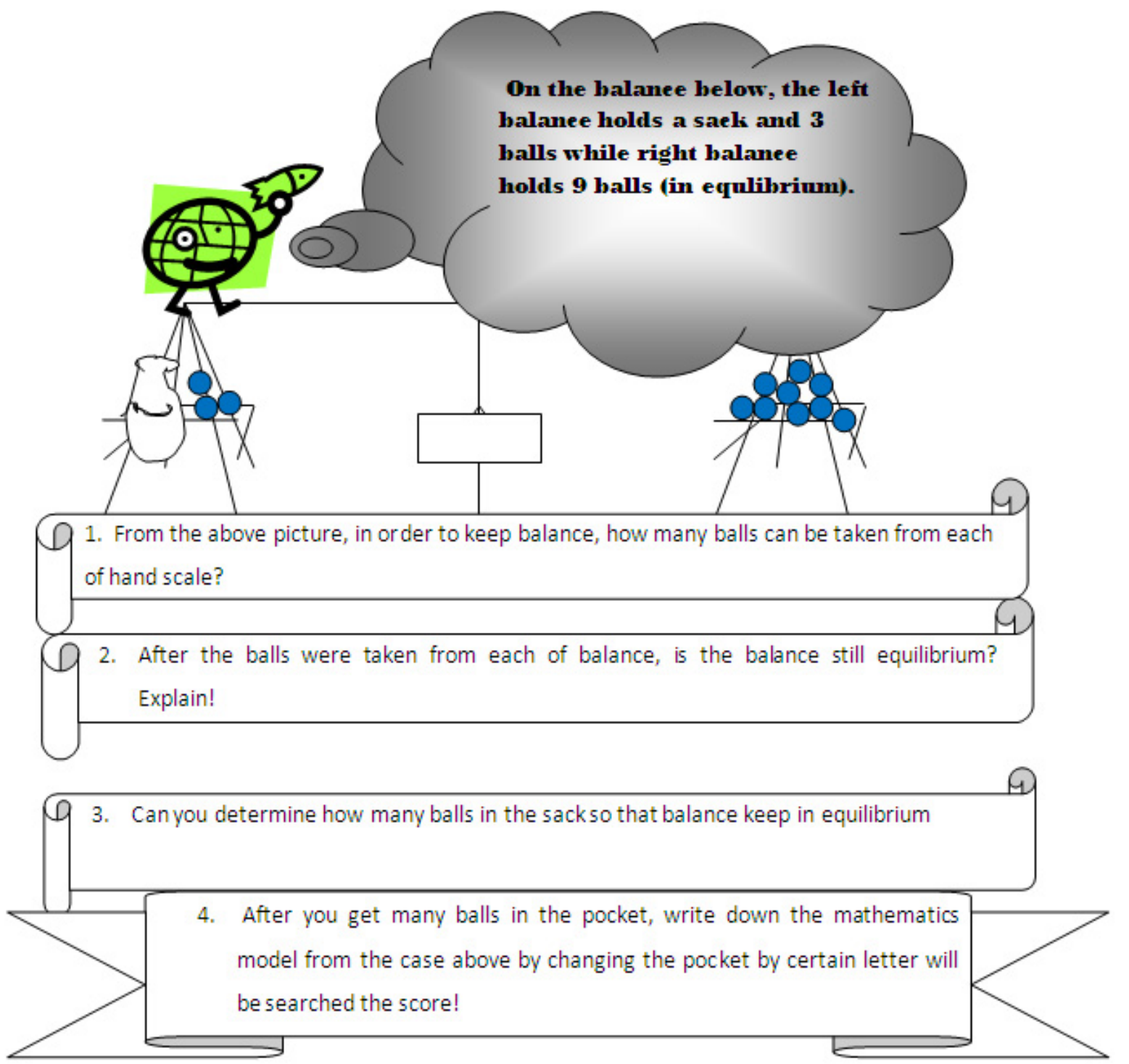

Figure 3. Student sheet

The findings indicated that either lesson plan or instrument exactly measured what should be measured in accordance to the material taught. The high reliability of the test indicated that it was consistent in repeated using. According to Arikunto (2013) the test then can be used for the purpose of the research.

The member of researchers' team, Muhammad (2013) found that the improvement of the students' mathematical communication ability that taught by contextual teaching and learning for all indicators is higher than those taught by ordinary learning. Rahmiyana (2013), found that the improvement of students' mathematical communication ability in STAD cooperative learning classroom is higher than those in direct instruction. Besides, there is no interaction between learning model and mathematical previous knowledge on the improvement of the students' mathematical communication ability. Hambali (2013) showed that the improvement of the students' mathematical concept understanding who taught by contextual teaching and learning (CTL) is significantly better than those got ordinary learning. Ahmad (2013) found, by qualitative analysis, that students' mathematical creative thinking and mathematical communication taught by realistic mathematical education is better than those taught by direct instruction.

The differences emerged caused by some factors either from STAD cooperative learning model or contextual teaching and learning (CTL) approach. Namely, learning, teacher, interaction, and learning material factor that make different. Besides, the students in that classrooms are more active while learning than their counterparts in directly or traditionally ones. 
In the part of learning model/approach factors, the researchers used those parts of model that focus on the students' activities. According to Suparno (1997), Ruseffendi (2004), Armanto (2001), Soedjadi (2004), Saragih (2009), learning models used are meaningful learning and very close to the core of constructivism. This is strengthened by Suparno (1997) and Saragih (2010) that the principles of constructivism are; (a) knowledge is built actively by students themselves; (b) the responsible of the learning process are the students; (c) teaching is assist students to learn; (d) teaching and learning process more be strengthened on the process than last result; (e) teacher is facilitator.

According to Davis (1996), constructivism in mathematics learning is oriented to (a) building knowledge through assimilation and accommodation process; (b) doing mathematics is answering what, how, and why; (c) new information should be in relating to previous experience through a logic framework by transforming, organizing, and interpreting the experiences; and (d) focus of learning is how the students think, not what he writes and says.

According to student-centered learning approach, knowledge is built by students themselves through exploring some situations and real world problems by mathematization process. Mathematics is not presented as a ready-made product to be transferred to the students by imitating, practicing repetition, and memorizing. In this case teachers are more expected create and pose problems (learning material) that very close to the students' daily life. It would endorse and encourage students to be more engaged individually or in group in the teaching and learning process, mainly in observing, investigating, and draw interesting conclusion from the given data, or making hypotheses. In such condition, students' creativity, skill and ability are empowerd and developed well. Mathematical concept understanding grasped will be more meaningful.

According to Suparno (1997), meaningful learning is a learning process where new information is connected by using available cognitive structure. It means that meaningful learning takes place when students attempt to connect new phenomenon to his knowledge structure. That is why students' previous knowledge is very important for a teacher. Moreover, notably the characteristics of contextual teaching and learning enable students to make difference in comparing to their counterpart in ordinary classroom. The differences are exposed clearly on students' answer sheet. In the traditional learning, students only work on similar exercises to the teacher exemplified. While in contextual classroom they are forced to solve problem of context given by teacher. By exploring the context of problem, the students' patterns of thinking are not limited only to text-book but even develop their own ways and steps assumed accurate.

Elsewhere, Saragih $(2009,2010)$ found that students' reasoning were improved through realistic mathematical education approach. Sinaga (2007) developed mathematics learning model based on bataknese culture and found that students' activities in teaching and learning process were improved. Some Postgraduate students of State University of Medan (Sitorus; 2011; Setiawan, 2010; Siahaan, 2011) found students' mathematical problem solving, mathematical connection, mathematical reasoning ability, and attitude towards mathematics and motivation were improved.

\section{Conclusion}

Based on the findings, it can be concluded that (1) as one of the goals of teaching mathematics to junior high school students, higher order mathematical thinking ability need serious attention (2) student-centered learning model with some learning approach significantly able to improve some mathematics competencies (doing math), students learning activity, students attitude toward mathematics and motivation.

\section{References}

Armanto, D. (2008-2009). Pengembangan Model Pembelajaran Matematika SD/MI Berbasis Kompetensi Dan Berkonteks Cerita Rakyat Sumatera Utara. Hibah Bersaing Research Report. Dirjen Dikti Depdiknas.

Carroll, W. M., \& Porter, D. (1998). Alternative algorithms for whole-number operations. In L. J. Morrow, \& M. J. Kenney (Eds.), The Teaching and Learning of Algorithms in School Mathematics, The 1998 NCTM Yearbook. Reston, Virginia: NCTM.

Fauzan, A. (2002). Applying realistic mathematics education in teaching geometry in Indonesian primary schools (Unpublished Doctoral dissertation). University of Twente, Enschede, The Netherlands.

Haji, S. (2005). Pengaruh Pendekatan Matematika Realistik terhadap Hasil Belajar Matematika di Sekolah Dasar (Unpublished doctoral dissertation). Postgraduate School UPI.

Herman, T. (2006). Pembelajaran Berbasis Masalah untuk Meningkatkan Kemampuan Berpikir Matematis Tingkat Tinggi Siswa Sekolah Menengah Pertama (SMP) (Unpublished doctoral dissertation). Postgraduate 
School UPI.

Manurung, R. B. (2010). Kemampuan Penalaran Formal siswa SMP Kodya Pematangsiantar dapat meningkat dengan Pendekatan Pembelajaran Matematika Realistik (Unpublished master thesis). Postgraduate Program State University of Medan.

Marpaung, Y. (2001). Implementasi Pendidikan Matematika Realistik di Indonesia. Makalah disampaikan pada Seminar Nasional Sehari: Penerapan Pendidikan Matematika Realistik pada Sekolah dan Madrasah, tgl 5 Nopember 2001, Medan: Tidak Diterbitkan.

National Council of Teacher of Mathematics. (2000). Principles and Standards for School Mathematics. Reston, VA: NCTM.

Puskur (2005). Kurikulum dan Hasil Belajar. Kompetensi Dasar Mata Pelajaran Matematika Sekolah Menengah Pertama dan Madrasah Tsanawiyah. Jakarta: Balitbang Depdiknas.

Ruseffendi, E. T. (1991). Pengantar kepada Membantu Guru Mengembangkan Kompetensinya dalam Pengajaran Matematika untuk Meningkatkan CBSA. Bandung: Tarsito.

Sabandar, J. (2001). Aspek Kontekstual dalam Pembelajaran Matematika. Makalah disampaikan pada Seminar Nasional Sehari: Penerapan Pendidikan Matematika Realistik pada Sekolah dan Madrasah, tgl 5 Nopember 2001, Medan: Unpublished.

Saragih, S. (2000). Pendekatan Cooperative Learning dalam Pembelajaran Struktur aljabar dengan Menggunakan Peta Konsep. Research Report Postgraduate Program State University of Medan.

Saragih, S. (2005). Pembelajaran Matematika dengan Peta Konsep, Alat Peraga, dan Belajar Kelompok. Jurnal Kependidikan Universitas Negeri Yogyakarta, 33(1), 53-62.

Saragih, S. (2006). Penerapan Cooperative Learning Dalam Pembelajaran Struktur Aljabar Dengan Menggunakan Modul. Majalah Ilmiah Pendidikan, Sains, Teknologi dan Seni, XVIII(21), 68-79.

Saragih, S. (2007). Mengembangkan Kemampuan Berpikir Logis dan Komunikasi Matematik Siswa Sekolah Menengah Pertama melalui Pendekatan Matematika Realistik (Unpublished Disertasi). Doktor pada PPS UPI.

Saragih, S. (2009). Pengembangan Berpikir Matematika Tingkat Tinggi Siswa SMP melalui Pendekatan Matematika Realistik. Hibah Bersaing Research Report Year I, Postgraduate Program State University of Medan.

Saragih, S. (2010). Pengembangan Berpikir Matematika Tingkat Tinggi Siswa SMP melalui Pendekatan Matematika Realistik. Hibah Bersaing Research Report Year II, Postgraduate Program State University of Medan.

Setiawan. (2010). Pengaruh Pendekatan Pembelajaran Dan Kontrol Lokus Terhadap Kemampuan Penalaran Matematika Siswa SMP (Master thesis at Postgraduate Program State University of Medan).

Siahaan, F. (2011). Pengaruh Strategi REACT Dan Sikap Siswa Terhadap Matematika Dalam Peningkatan Kemampuan Koneksi Dan Pemecahan Masalah Matematik Siswa SMA (Master Thesis Master Thesis at Postgraduate Program State University of Medan).

Sinaga, B. (2007). Pengembangan model pembelajaran matematika berbasis budaya batak (Unpublished doctoral dissertation). Unesa Surabaya.

Sitorus, A. (2011). Kemampuan Pemecahan Masalah dan Penalaran Siswa SMA Kab. Asahan dapat meningkat dengan menerapkan Strategi Pembelajaran Peningkatan Kemampuan Berpikir (SPPKB) (Master Thesis, Postgraduate Program State University of Medan).

Sumarmo, U. (2002). Alternatif Pembelajaran Matematika dalam Menerapkan Kurikulum Berbasis Kompetensi. Makalah pada Seminar Tingkat Nasional FPMIPA UPI: Unpublished.

Sumarmo, U. (2005). Pengembangan Berfikir Matematik Tingkat Tinggi Siswa SLTP dan SMU serta Mahasiswa Strata Satu (S1) melalui Berbagai Pendekatan Pembelajaran. Research Report, Research Council UPI: Unpublished.

Suparno, P. (1997). Filsafat Konstruktivisme dalam Pendidikan. Yogyakarta: Kanisius. 


\section{Copyrights}

Copyright for this article is retained by the author(s), with first publication rights granted to the journal.

This is an open-access article distributed under the terms and conditions of the Creative Commons Attribution license (http://creativecommons.org/licenses/by/3.0/). 